\title{
Production of Organic Seeds in Poland
}

\author{
Magdalena SZPAKOWSKA ${ }^{1 *}$, Roman HOŁUBOWICZ ${ }^{1}$ \\ ${ }^{1}$ Poznań University of Life Sciences, Faculty of Horticulture and Landscape Architecture, \\ Department of Plant Pathology, Seed Science and Technology, Baranowo, ul. Szamotulska \\ 28, 62-081 Przeźmierowo, Poland \\ *)corresponding author, e-mail: magda_szpakowska@wp.pl.
}

BulletinUASVM Horticulture 72(2) / 2015

Print ISSN 1843-5254, Electronic ISSN 1843-5394

DOI:10.15835/buasvmcn-hort:10976

\begin{abstract}
Organic seeds are the ones which are produced without any fertilizers and pesticides, except those based on copper or sulphur. Since many years, one has been observing in Poland an increase in the number of farms producing organic food. Their owners can apply for a direct payment from the special European Union programme. In 2014, a survey was carried out in 5 agricultural and 5 horticultural most important seed companies on their production of organic seeds. It was done through personal contacts with the people responsible for seed company marketing. In Poland, only 4 seed companies produce organic seeds. They are of onion, carrot, tomato, basil, broad bean, beetroot, zucchini, cucumber, dill, parsley, broccoli, pumpkin, pea, leek, watercress, chive, radish, spinach and common bean as well as cereals and legumes. The present EU law regulations concerning organic food and seeds are not creating a market demand for organic seed production. By collecting data from 10 most important agricultural and horticultural Polish seeds companies, the picture was created about domestic offer of organic seeds in the years 2008-2014.
\end{abstract}

Keywords: ecological, organic, seeds.

\section{INTRODUCTION}

For many years, in Poland, one can observe a growing number of organic farms producing healthy food. Their number increased from 27 in 1990 to over 26 thousand in 2014. Polish farmers for organic food production use only $5.4 \%$ of their production fields (Fajerski, 2014a,b). It also helps them that since 2004, when Poland had become a member of the European Union (EU), organic farms can apply for direct subsidization from the EU programme. The biggest increase of organic farms in Poland was recorded for Mazowsze (Central Poland) and Lublin area (East Poland) (Liu, Hołubowicz, 2012). The farms in these areas area are not so large and effective as in Wielkopolska (Western Poland), and they, therefore, see in organic farming a chance for development. Polish organic farmers often work in groups - they have their own branch union, take part in extension courses and are known as people with a great passion for agriculture. Since 2006, the EU (since 2000 in the US) had law, according to which, organic food can be produced only from especially prepared for this purpose seeds called organic ones. This law resulted in launching by Polish seed companies, following an example of Western companies, a new product on the market - organic seeds.

First Polish seed company to introduce organic seeds on the domestic market was TORSSED S.A. from Torun. For this new at that time product, they were rewarded in 2002 on the "Polagra" exhibition which, for many years was the most prestigious agro-horticultural event in Poland, with the Golden Medal. In the years 2008-2011, the organic seeds in Poland were produced by 4 seed companies: CNOS - Poznań, Ltd. (3), PlantiCo - Zielonki, Ltd (8), TORSEED SA (9) and ROLNAS (10) (Fig. 1). Many other seed companies, however, including the foreign ones, operating on the Polish seed market, offered organic seeds. The most important vegetable species, of which organic 
seeds were offered on the Polish market were: carrot, cucumber, onion, head white cabbage, dill and lettuce. The client expects that these seeds will give plants with resistance $(70 \%$ of the plants in the field healthy) or tolerance (30-40\%) to certain diseases or pests. Moreover, that they had been produced on the plantations, on which no fertilizers and pesticides (except these based on copper and sulfur) were used. They should be also processed and stored separately. Their genetic and physical quality, however, should be the same as conventional seeds (Hołubowicz, 2009).

\section{MATERIALS AND METHODS}

The authors had to make a decision on what bases to select seed companies for the study and how many of them to take to have the search most objective. In the years 2008-2014, there were almost 1000 seed companies operating on the Polish market (Hołubowicz, 2015). In the case of number of the seed companies, eventually only 5 agricultural and 5 horticultural ones had been selected. In the first group, the ones with the highest value of the annual turnover were selected. In the horticultural seed companies selection, the criterion was not turnover but the amount of pictorial seed bags provided on the retail market. The table 1 gives the newest available data.

The figure 1 also gives their location in Poland. We also provide a short characteristic of all seed companies in our research. These are:

1. Spójnia-Nochowo is located near Śrem (western Poland). It was started in 1917 as a private company, then (1950-1958) it was nationalized. It uses advanced improving seed quality methods and it has tradition. It is highly profitable, small company, with very strong plant breeding as well as domestic and foreign seed production.

2. Poznańska Hodowla Roślin (official English name: Poznań Plant Breeders) is located near Poznań. It is a state-owned strategic company. It is the biggest agriculture plant breeding and seed

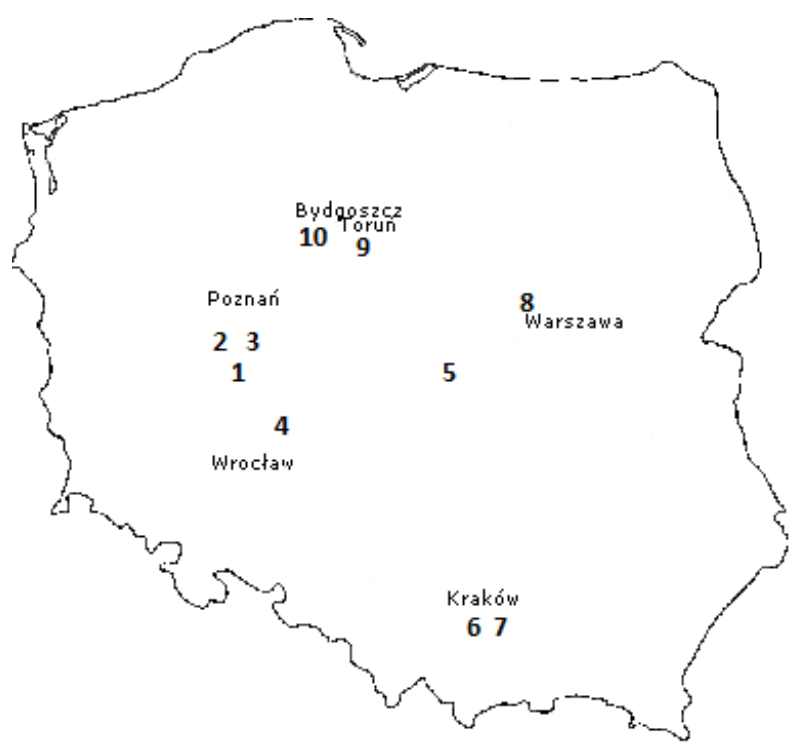

Fig. 1. Map of Poland with location of 10 most important seed companies investigated in the research (See the text for explanation of the numbers and companies)

Tab. 1. Amateur market vegetable and flowers retail seeds suppliers (in millions of pictorial bags) in Poland, in the trade season 2011/12 and trade prediction for 2015

\begin{tabular}{|c|c|c|c|}
\hline Seed company's name & $\begin{array}{c}\text { Number of vegetable } \\
\text { species }\end{array}$ & Flower species & In 2015 \\
\hline Vilmorin - Garden & $18\left(8^{*}\right)$ & $6\left(7^{*}\right)$ & the same \\
\hline CNOS Ożarów Mazowiecki & $15(12 *)$ & 3 & decrease \\
\hline W. Legutko & 6 & 4 & increase \\
\hline PlantiCo Zielonki & 6 & 2 & icrease \\
\hline Polan Kraków & 6 & 2 & increase \\
\hline TORSEED SA Toruń & $6\left(3^{*}\right)$ & $2\left(1^{*}\right)$ & decrease \\
\hline Spójnia Nochowo & $4\left(3^{*}\right)$ & 1 & decrease \\
\hline Rekwiat & - & 2 & increase \\
\hline $\begin{array}{l}\text { Others: Lidl, Netto, Biedronka, Real, } \\
\text { Lobelia, Roltico, Selecta, Greenland, } \\
\text { Vomir, Centrala Nasienna - Głogów }\end{array}$ & 8 & 2 & increase \\
\hline
\end{tabular}


production company in Poland. Today, it has 12 units all over Poland.

3. Vilmorin Garden is a company established in 1999 as CNOS - Vilmorin Polish French joint venture. Vilmorin Clause \& Cie Group had become its majority shareholder (51\%). It is a global leader on the market of seeds of vegetables, flowers and herbs. The remaining shares have been assigned to the Poznan-based company CNOS PNO. Today, Vilmorin Garden constitutes an absolute ownership of French Vilmorin Jardin. Its business activity includes two areas: professional sector, within which it is the second largest company in the world and amateur sector, within which it is a global leader with its companies all over the world.

4. W. Legutko started in 1992 and it is located in Jutrosin near Rawicz (South-west Poland). It is a private company and a family business. It has the bigger flower seeds offer in the EU, with the largest (over 75\%) seed export of horticultural seeds outside Poland.

5. Kutnowska Hodowla Burka Cukrowego is located in Straszków near Kłodawa (Middle Poland). It was started in 1886 as a family business. Now, it is state-owned. All their seeds are multiplied in Italy and France. The seeds from this company are one of the best in the world.

6. Polan is located in Cracow, in the south of Poland. It is state-owned company. It is the oldest (over 80 years) Polish horticulture seed company. It has got the biggest achievements in breeding vegetables, especially cucumber, common bean, onion, field tomato and garden carrot.

7. Małopolska Hodowla Roślin is located in Cracow. It is a state-owned company. This is the only Polish company specializing in producing fodder beet seeds. It exports them to many former socialistic countries, such as White Russia, Ukraine, Romania and Slovakia.

8. PlantiCo Zielonki was founded in 1899. It is the biggest and the most important horticultural seed company in Poland. At present, it develops cultivars and produces seeds of vegetable and flower species. It has very strong plant breeding and the most modern seed processing facilities in the country.

9. TORSEED SA is located in Toruń (Northern Poland). Its name, TORSEED, has been formally used since 1999. It is a private company. It is the only share holder private seed company in horticulture in Poland. Almost 50\% of its stocks have been bought by the seed growers and dealers. It has weak breeding but strong marketing. The company has also 3 garden centres.

10. ROLNAS is located in Bydgoszcz. It came out from a former collapsing state-owned agricultural seed companies. It is now a private company and a family business. It has no breeding programmes, but only seed production and trade. It exports seeds on the Germany and US markets (Zhang, Hołubowicz, 2015).

All the data about organic seeds were collected through personal contacts with the people responsible for seed company marketing in the companies.

\section{RESULTS AND DISCUSSION}

In the years 2008-2010, 4 Polish seed companies offered organic seeds of vegetables and one of agricultural crops (Table 2). In the years 2008-2014, 3 of them gave up production of the seeds. Only 2 Polish seeds companies, in 2014, offered organic seeds to organic farmers. These were PlantiCo Zielonki (20 species of vegetables, offer covers all important vegetables grown in Poland) and "ROLNAS" (cereals and legumes). This was due to smaller and smaller demand from the market. Most of organic food producers in Poland no longer asked for organic seeds and use seeds of only conventional cultivars.

The production of organic seeds in Poland is facing a few problems, the biggest one is lack of cultivars with resistance or tolerance to certain diseases or pests. A good example here is an onion downy mildew - a disease, which in Poland has been the biggest problem in seed production of this species. It is caused by the fungus Peronospora destructor (Berk.) Casp. Its spores are spread out by wind.

Lack of cultivars with genetic resistance to diseases and pests comes from the fact that for many years, the breeding programmes in Poland and many other leading in seed production countries, were orientated for quantity not quality characters, such as e.g. yield. Resistance, in those programmes, was second or third priority, so the breeders simply rejected the lines with small yield despite any other good characters.

When organic seeds had come on the market, this breeding priority order changed: at that moment, the resistance became the highest one. The critical issue is: where to get such cultivars with resistance 
Tab. 2. Organic seeds production in the Polish seed companies

\begin{tabular}{|c|c|c|c|c|c|c|}
\hline $\begin{array}{c}\text { Company's } \\
\text { Name }^{*}\end{array}$ & $\begin{array}{l}\text { organic } \\
\text { seeds in } \\
\text { the past }\end{array}$ & $\begin{array}{l}\text { organic } \\
\text { seeds at } \\
\text { present }\end{array}$ & $\begin{array}{l}\text { organic } \\
\text { seeds in } \\
\text { production }\end{array}$ & $\begin{array}{l}\text { organic seeds } \\
\text { in the trade } \\
\text { offer }\end{array}$ & crops & $\begin{array}{l}\text { trend in the } \\
\text { future }\end{array}$ \\
\hline 1. & no & no & no & no & - & no \\
\hline 2. & no & no & no & no & - & no \\
\hline 3. & yes & yes & yes & yes & $\begin{array}{l}\text { carrot, beetroot, } \\
\text { tomato, bean, broccoli, } \\
\text { cucumber, onion, pea, } \\
\text { pumpkin, lettuce, leek, } \\
\text { spinach, basil, dill, }\end{array}$ & yes \\
\hline 4. & no & no & no & no & - & no \\
\hline 5. & no & no & no & no & - & no \\
\hline 6. & no & no & no & no & - & no \\
\hline 7. & no & no & no & no & - & no \\
\hline 8. & yes & yes & yes & yes & $\begin{array}{l}\text { onion, carrot, beetroot, } \\
\text { radish, tomato, bean, } \\
\text { broad bean, cucumber, }\end{array}$ & yes \\
\hline 9. & yes & no & no & no & - & $\mathrm{YC}^{* *}$ \\
\hline 10. & yes & yes & yes & yes & cereals and legumes & yes \\
\hline $\begin{aligned} \text { R}^{*} \text { Company's name } \\
\text { **Yes, but under ce } \\
\text { 1. "Spójnia } \\
\text { 2. Poznańs } \\
\text { 3. Vilmorin } \\
\text { 4. W. Legut } \\
\text { 5. Kutnows } \\
\text { 6. Krakows } \\
\text { 7. Małopol } \\
\text { 8. PlantiCo } \\
\text { 9. TORSEE } \\
\text { 10. Przedsie }\end{aligned}$ & $\begin{array}{l}\text { ain conditior } \\
\text { Hodowla i Na } \\
\text { a Hodowla Rc } \\
\text { Garden Sp. z } \\
\text { o Przedsiębic } \\
\text { a Hodowla B } \\
\text { a Hodowla i } \\
\text { a Hodowla R } \\
\text { Hodowla i N } \\
\text { - Przedsiębi } \\
\text { iorstwo Nasi }\end{array}$ & $\begin{array}{l} \\
\text { iennictwo } 0 \\
\text { ślin Sp. z o. o } \\
\text { o. } \\
\text { rstwo Hodov } \\
\text { raka Cukrov } \\
\text { asiennictwo } \\
\text { ślin Sp. z o.c } \\
\text { siennictwo } \\
\text { rstwo Nasier } \\
\text { nne ROLNAS }\end{array}$ & $\begin{array}{l}\text { rodnicze Sp. z o. } \\
\text { lano-Nasienne S } \\
\text { go Sp.z o.o. } \\
\text { grodnicze Polar } \\
\text { grodnicze Zielon } \\
\text { hictwa Ogrodnic } \\
\text { Sp. z o.o. }\end{array}$ & $\begin{array}{l}\text { o. } \\
\text { p. z o.o. } \\
\text { Sp. z o.o. } \\
\text { ki Sp. z o.o. } \\
\text { zego i Szkółkarstw }\end{array}$ & S.A. & \\
\hline
\end{tabular}

from? Without these sources of characters (breeding starting materials) any creative breeding cannot be started. There is also a possibility to use in the breeding programme wild plant species, which undoubtedly have this character. Thus, giving them through crossing other useful quality characters connected with yield will take many years and will thereby cost seed companies a lot of money. Other option is gene banks and old cultivar collections. Such breeding lines with genetic resistance are still kept in Poland and are available on request. Theoretically, there is also another option: artificial resistance gene(s) transfer, but in the EU countries, GMO, legally (except 2 cultivars of agricultural crops) are still not allowed. So far, only one cultivar of maize and potato were allowed to be registered in the European Catalogue and then launched on the market. In Poland, there is additionally an ethical objection to GMO, as almost all seed growers are Roman Catholics and their religion has not accepted this breeding technology.

The second big problem with organic seeds in Poland is a limited market demand for them. Polish seed growers and organic farmers use a strategy to avoid or detour the requirement to use them. They do it by asking a seed company for a written statement that they have in their offer no cultivar of a given species and group with a resistance to a given disease or pest. This, according the present law regulation, allows them to use a conventional cultivar in production of organic food. As a result of this practice, the demand for organic seeds, despite increase in production of healthy food, has been decreasing. In these circumstances, Polish companies seriously considered a possibility of giving up production of organic seeds.

Another serious problem for a seed company to produce organic seeds in Poland is their cost of production. It is a few times higher than the one 
Tab. 3. Ten most important polish seed companies

\begin{tabular}{|c|c|c|c|c|c|}
\hline Company's name * & legal status & main crops & activity area** & main clients ${ }^{* * *}$ & $\begin{array}{c}\text { profitability } \\
\text { of the company }\end{array}$ \\
\hline 1. & state-owned & vegetables (52) & PB, SP, ST & $\mathrm{AM}$ & good \\
\hline 2. & state-owned & $\begin{array}{c}\text { grasses (14), } \\
\text { cereals (12) }\end{array}$ & PB, SP, ST & PM & good \\
\hline 3. & private & $\begin{array}{l}\text { vegetables (600), } \\
\text { flowers }(400)\end{array}$ & ST & $\mathrm{AM}, \mathrm{PM}$ & very high \\
\hline 4. & private & $\begin{array}{c}\text { vegetables } \\
(1000), \text { flowers } \\
(2000)\end{array}$ & PB, SP, ST & $\mathrm{AM}$ & very high \\
\hline 5. & state-owned & sugar beet (9) & PB, SP, ST & $\mathrm{PM}$ & good \\
\hline 6. & state-owned & $\begin{array}{c}\text { vegetables (56), } \\
\text { flowers (94) }\end{array}$ & PB, SP, ST & $\mathrm{AM}$ & bad \\
\hline 7. & state-owned & $\begin{array}{c}\text { cereals }(22), \\
\text { legumes }(11), \\
\text { grasses }(40)\end{array}$ & PB, SP, ST & PM & good \\
\hline 8. & state-owned & $\begin{array}{l}\text { vegetables (122), } \\
\text { flowers (59) }\end{array}$ & PB, SP, ST & $\mathrm{AM}$ & very high \\
\hline 9. & private & $\begin{array}{l}\text { cucumber (8), } \\
\text { onion (6) }\end{array}$ & PB, SP, ST & $\mathrm{AM}$ & good \\
\hline 10. & private & $\begin{array}{l}\text { cereals }(120), \\
\text { potatoes }(30), \\
\text { grasses }(30)\end{array}$ & SP, ST & PM & good \\
\hline
\end{tabular}

of the conventional seeds (Hołubowicz, Wojtasik, 2009). It comes from the fact that the organic seeds are produced on the fields, on which no fertilizers are allowed to be used (Hołubowicz, 2009). As an alternative of fertilizing in the production of organic seeds, the leaves of the seed plants are sprayed with a solution made of 2 species of rotten nettle (Urtica dioica L. or U. urens L.) (Photo 1.). In order to control aphids on the organic seed plantations, the plants are sprayed with the solution made of garlic. The other way to control insects on the seed plants in the field is to cover plants with a thin material, so there is a physical barrier and the insects cannot contact the plants, for example, young cabbage plants in the place of production are protected this way against the cabbage fly. The exact moment of covering the young cabbage plants with the material is based on the observations of development of the insects, which are trapped into a special trapping cage (Photo 2.). Another way, sometimes used in organic production, is to grow 2 different crops at the same time, for example, one row of carrot and then one row of onion plants (Lampkin, Padel, 1994).
This way the fragrances of both plants discourage insects to fly over and damage the plants. The organic seed growers have been recently put in the position of having nothing organic to dress seeds with. We strongly suggest to try using some plant and tree extracts for this purpose, e.g. an oil from a camphor tree (Cinnamonum camphora L.) tree (Deng et al. 2004, Liu et al., 2006).

Additionally, organic seeds must also be processed and graded using separate machines and processing lines. The same refers to their storage: in the seed storage house, they must be clearly separated from any conventional seeds. The quality of organic seeds, however, should be exactly the same as the conventional seeds. All these requirements significantly increase the final costs of the organic seeds (Bralewski, Hołubowicz, 2004).

Recently, in Poland, there is also a new niche of the market for organic seeds: amateur gardeners. Together with a trend for healthy diet, called 'Slow Food' or healthy life called 'Slow Life' strongly announced by mass media (Chabzda, 2014), comes the idea of producing your own vegetables 


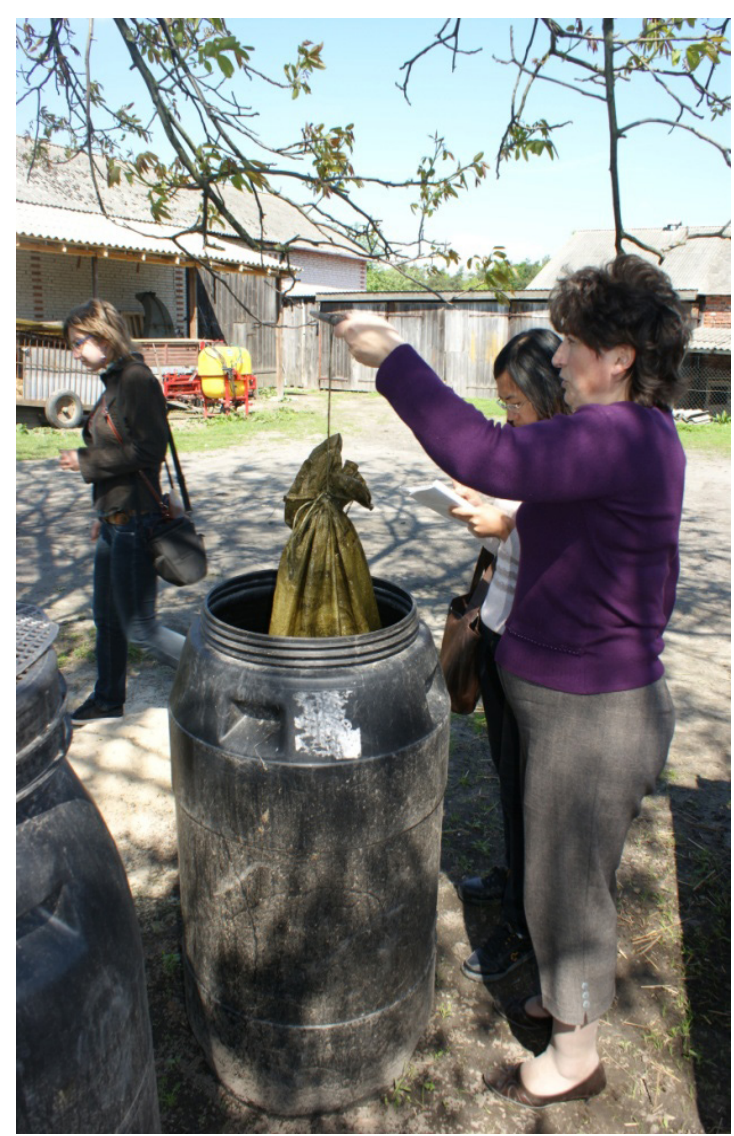

Photo 1. Preparing solution of rotten nettle

called in the TV and women's magazines: "Grown your own". This should be promoted with the use of organic seeds. For hobby market, the higher price of the organic seeds, when sold in small amount, should not be a problem as the carried our research had shown. However, the key factor here will be a various and interesting cultivar offer (Hołubowicz, 2007).

As increasing production of organic food in Poland is continuing, the future of organic seeds market in Poland is not so sure any more. The demand for them is small, the processing and storage requirements for the industry - high. This in turn, increases their production costs, i.e. their economic risk. On the other side, the organic seed growers, due to seed lower yields and bigger problems to keep the quality standards, ask for 2-3 times higher delivery prices, for what the Polish seed companies cannot agree. As a result some of them had already given up the co-operation, whereas the others make strict calculations before the final decision.

Polish seed companies should think about international co-operation in organic seeds

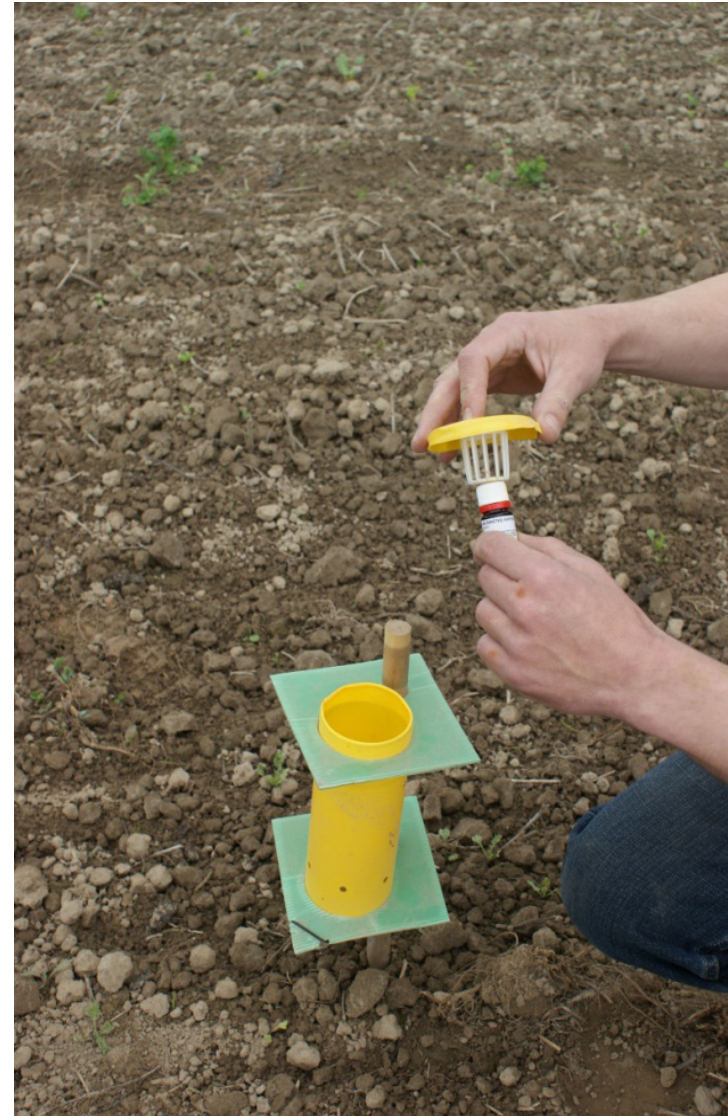

Photo 2. Cabbage fly trap

production and should learn from the best Italian and French companies. Seed companies need to make bigger offer for Polish amateur market.

\section{CONCLUSION}

The present EU law regulations concerning organic food and seeds are not creating a market demand for organic seed production. This is because there is a shortage of cultivars for agriculture and horticulture with resistance or tolerance to diseases and pest. After change of the law, all responding seed companies claimed they would come back to the production of the seeds.

\section{REFERENCES}

1. Bralewski TW, Hołubowicz R (2004). Seeds for organic production. Owoce Warzywa Kwiaty, 7: 44 (in Polish).

2. Chabzda P (2014). Biblia Slow Life. Slow Life Food \& Garden. Top Media \& Publishing House, Poznań. 16: 1417.

3. Deng YX, Wang JJ, Zhang HY (2004). Comparison of Fumigation Activities of 9 Kinds of Essential Oils Against the Adults of Maize Weevil (Sitophilus zeamais L., Motschulsky). Chin. J. Pesticide Sci., 6(3), 85-88. 
4. Fajerski M (2014a). Development of organic agriculture and processing in Poland.

5. Ekodostawcy, XI 2014, 4(4), 11-13 (in Polish).

6. Fajerski M (2014b). Field to develop - organic farms in the Eastern Block countries.Ekodostawcy, IX 2014, 2(2), 6-7 (in Polish).

7. Hołubowicz R (2007). Ogólna uprawa warzyw (Vegetables Seeds Production), In "Vegetables Production. General Aspects”(ed. M. Knaflewski), PWRiL, Poznań, 387-397 (in Polish).

8. Hołubowicz R, Wojtasik J (2009). Cost of organic and conventional production of common bean seeds (Phaseolus vulgaris L.) in Poland. Acta hort. reg. 12: 183185.

9. Hołubowicz R (2009). Organic seeds - challenges and threats for seed companies. Proc. Of the Conf. "Climate, Ecology and Agriculture In Euroasia", Irkutsk, 25-29 May, 2009, 567-571.
10. Hołubowicz R (2015). Plant breeding, seed production and technology. In "Selected Topics in Horticulture" (ed. R. Hołubowicz), Poznań Univ. Life Sci. Publ. Unit, Poznań 2015, 7-30 (in press).

11. Lampkin NH, Padel S (1994). Organic farming: sustainable agriculture in practice. In: "The Economics of Organic Farming" (Eds. N.H. Lampkin and S. Padel) CAB: Wallingford, UK:3-8.

12. Liu CH, Mishra AK, Tan RX, Tang C, Yang H, Shen YF (2006). Repellent and Insecticidal Activities of Essential Oils from Artemisia princeps and Cinnamomum camphora L. And their Effect on Seed Germination of Wheat and Broad Bean, Biores. Technol. 97(15), 1969-1973.

13. Liu Q, Hołubowicz R (2012). Use of Organic Seeds in Selected Farms in the Area of Lublin (Eastern Poland). Bull. UASVM Hort., 69: 213-218.

14. Zhang WD, Hołubowicz R (2012). Outsourcing in selected Polish seed companies. Guangdong Agric. Sci, 39: 213217. 